\title{
PENGGUNAAN MADU TOPIKAL EFEKTIF TERHADAP PENYEMBUHAN LUKA KRONIS
}

\author{
Etty $^{1}$, Yuliana Syam ${ }^{2}$, Saldy Yusuf ${ }^{3}$ \\ Rumah Sakit Umum Daerah H. Andi Sulthan Daeng Radja Bulukumba ${ }^{1}$ \\ Universitas Hasanuddin Makassar ${ }^{2,3}$ \\ ethyamirah@gmail.com ${ }^{1}$
}

\begin{abstract}
ABSTRAK
Tujuan penelitian ini adalah untuk mengetahui efektivitas madu topikal terhadap penyembuhan luka kronis.Metode penelitian ini menggunakan metodetinjauan literatur dengan menggunakan lima database dalam pencarian artikel yaitu pubmed, proquest, science direct, wiley online library dan google scholar.Hasil tinjauan literatur adalah dari enam artikel penelitian yang dianalisis, lima artikel penelitian menunjukkan bahwa madu efektif terhadap penyembuhan luka kronis dibandingkan dengan normal saline, povidone iodine dan terapi lainnya (nilai $\mathrm{p}<0.05$ ), namun ada satu artikel tidak signifikan secara statistik. Simpulan, penggunaan madu sebagai salah satu terapi topikal yang efektif dalam perawatan luka kronis dikarenakan kandungan nutrisi atau khasiat dari madu.
\end{abstract}

Kata Kunci: Luka Kronis, Madu, Penyembuhan Luka, Ulkus

\section{ABSTRACT}

The aim of this study was to determine the effectiveness of topical honey in chronic wound healing. This research method uses a literature review method using five databases in search of articles, namely Pubmed, ProQuest, Science Direct, Wiley Online Library, and Google Scholar. The results of the literature review are from six research articles analyzed, five research articles showed that honey was effective against chronic wound healing compared to normal saline, povidone iodine and other therapies ( $p$ value <0.05), but one article was not statistically significant. In conclusion, the use of honey as a topical therapy which is effective in treating chronic wounds is due to the nutritional content or properties of honey.

Keywords: Chronic Wounds, Honey, Wound Healing, Ulcers

\section{PENDAHULUAN}

Perawatan luka merupakan salah satu tindakan keperawatan mandiri perawat yang sangat menantang di fasilitas pelayanan kesehatan terutama bila menjumpai luka infeksi atau luka kronis. Luka kronis adalah luka akut dengan waktu penyembuhan yang lama, biasa disebut dengan penyembuhan luka yang tertunda, hal ini disebabkan karena faktor infeksi (Han \& Ceilley, 2017). Infeksi, trauma berulang dan penyakit vascular lokal merupakan faktor penyebab terjadinya luka kronis, seperti Diabetic Foot Ulcer (DFU), ulkus pembuluh darah vena dan arteri, luka tekan dan luka abses lainnya (Zhang et al., 2020). Penanganan luka kronis tidak bisa dianggap remeh, membutuhkan perawatan 
yang berfokus pada pasien, efektivitas biaya dan multidisiplin (Joret et al., 2019). Ada berbagai penanganan luka kronis yang biasa dilakukan seperti debridement, pemberian obat sistemik dan perawatan luka (Zhang et al., 2020). Perawatan terbaik dan optimal dalam pengelolaan luka adalah dengan mempertahankan lingkungan dalam keadaan lembab (moisture balance) dengan menggunakan bahan-bahan dan metode yang mempercepat kontraksi luka, mencegah terbentuknya jaringan granulasi yang berlebihan, mencegah pertumbuhan bakteridan sebagai pelembab yang sesuai untuk mempercepat proses penyembuhan luka (Weller et al., 2019).

Proses penyembuhan luka adalah suatu proses yang secara normal akan terjadi pada setiap individu yang mengalami luka, artinya setiap terjadi luka, mekanisme tubuh akan mengupayakan pengembalian komponen jaringan yang rusak dengan membentuk struktur baru dan fungsional yang sama halnya dengan sebelumnya sesuai dengan fase penyembuhan luka (Wang et al., 2018). Madu adalah salah satu terapi topikal yang digunakan dalam tinjauan literatur ini. Madu telah dikenal sejak zaman kuno yang digunakan sebagai pengobatan luka, baik luka akut maupun luka kronis. Madu dapat mempertahankan kelembaban, merangsang pertumbuhan jaringan, angiogenesis, granulasi, kontraksi luka, merangsang sintesis kolagen, memfasilitasi debridement dan mempercepat epitelisasi luka (Cohen-Mansfield et al., 2017). Madu sangat bermanfaat bagi kesehatan khususnya terhadap penyembuhan luka, hal ini dibuktikan oleh beberapa penelitian.

Beberapa penelitian sebelumnya telah dilakukan untuk melihat manfaat madu terhadap penyembuhan luka. Madu memiliki sifat sebagai anti mikrobial, anti inflamasi, anti oksidan serta anti septik (Ghazali et al., 2017; Dzugan et al., 2018; Henatsch et al., 2018). Penelitian lain melaporkan bahwa madu dinilai efektif dalam penyembuhan luka dan proses perbaikan jaringan serta mengurangi jaringan parut atau tanpa pembentukan bekas luka (Martinotti \& Ranzato, 2018). Hal ini sesuai dengan literature yang menjelaskan bahwa madu memiliki potensi dalam proses penyembuhan luka dan bertanggung jawab terhadap aktivitas anti bakteri, aktivitas anti inflamasi, aktivitas anti oksidan, aktivitas anti virus, anti jamur serta meningkatkan sistem kekebalan tubuh (Nweze et al., 2020).

Moisture balance merupakan salah satu prinsip dalam perawatan luka yaitu mempertahankan isolasi lingkungan luka tetap lembab, dengan menggunakan balutan penahan kelembaban, oklusive, semi oklusive, tujuannya menciptakan lingkungan yang kondusif untuk melindungi luka dan kulit sekitar luka, meningkatkan kenyamanan pasien, mengurangi nyeri pada ujung saraf dan mempertahankan suhu (Ose et al., 2018). Hal ini sejalan dengan penelitian yang melaporkan bahwa madu dapat menjaga kelembaban luka dan menjaga batas protektif untuk meminimalisir kontak antara luka dan agen infeksi (Meo et al., 2017). Dengan menggunakan bahan madu topikal akan lebih bersifat menguntungkan artinya aman, ekonomis, mudah didapat dan tidak berisiko. Oleh karena itu, penerapan madu efektif dalam proses penyembuhan luka kronis dapat dibahas dan dianalisis secara lengkap dalam tinjauan literatur ini.

\section{METODE PENELITIAN}

Metode penelitian ini adalah tinjauan literatur. Tinjauan literatur ini menggunakan penelusuran hasil publikasi ilmiah dalam rentang tahun 2017-2020 dengan menggunakan lima database dalam pencarian artikel yaitu pubmed, proquest, sciencedirect, wiley online library, dan garuda dengan kata kunci berdasarkan metode PICO/Patient, Intervention, Comparison and Outcome. Setiap database menggunakan kata kunci antara lain: 


\section{P:Chronic Wound OR Chronic Ulcer OR Venous Ulcer}

\section{I: Honey \\ C: No Intervention OR Standard Care OR Control OR Placebo \\ O: Wound Heal OR Heal OR Healing.}

Ditemukan 2.947 artikel, kemudian dilakukan skrining dan uji kelayakann artikel dengan mengeksklusikan artikel yang tidak sesuai dengan kriterian inklusi, sehingga ditemukan 5 artikel yang memenuhi kriteria inklusi dan relevan dengan pertanyaan penelitian (Gambar 1). Kriteria inklusi pada tinjauan literatur ini antara lain: (1) artikel yang sesuai dengan tujuan penelitian (2) full text (3) berbahasa Inggris (4) tahun publikasi 2017-2020 (5) artikel dengan intervensi menggunakan madu topikal (6) Hasil penelitian menunjukkan efektivitas madu terhadap penyembuhan luka kronis. Sedangkan kriteria eksklusi antara lain (1) animal study (2) hasil kualitatif study. Desain penelitian dalam tinjauan literature ini adalah a prospective randomized study, prospective pilot randomized control study, aprospective study, a prospective observational study, a prospective interventional study dan RCT.

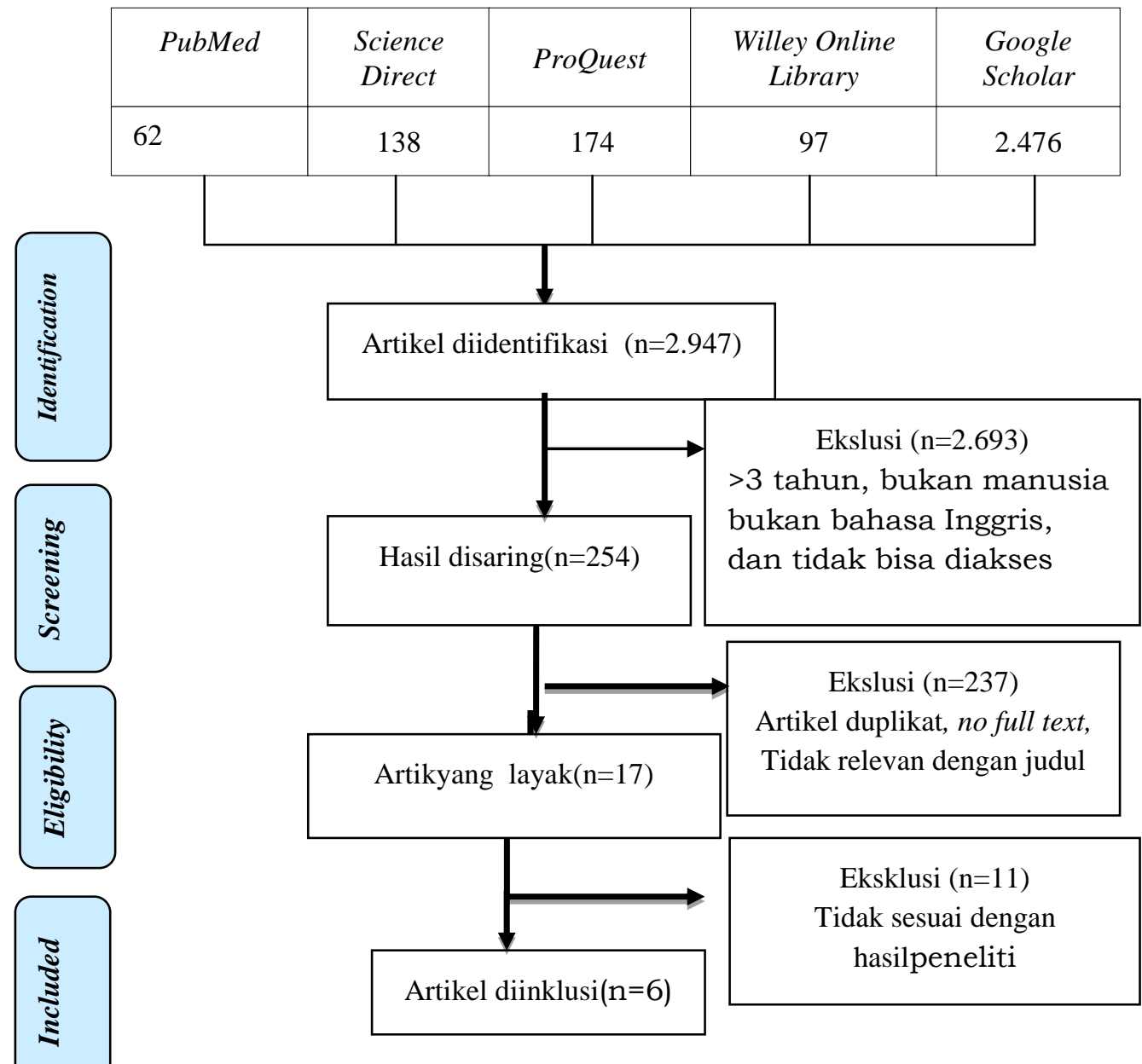

Gambar. 1

Flow Diagram Pemilihan Studi 


\section{HASIL PENELITIAN}

Berdasarkan hasil pencarian literatur ditemukan enam artikel yang memenuhi kriteria inklusi dan umumnya menilai efek madu terhadap proses penyembuhan luka kronis. Artikel penelitian ini didapatkan melalui penelusuran hasil publikasi ilmiah dengan rentang waktu tiga tahun terakhir (2017-2020). Didapatkan sebanyak tiga artikel penelitian di India, satu artikel penelitian di Iran, satu artikel penelitian di Hongkong, dan satu artikel penelitian di Republik Ceko, dengan jumlah sampel antara 15 sampai 64 responden.

Tabel. 1

Deskripsi Studi dan Hasil Studi

\begin{tabular}{|c|c|c|c|}
\hline No & Author & $\begin{array}{c}\text { Tujuan Penelitian, Desain } \\
\text { Penelitian, dan Jumlah sampel }\end{array}$ & Hasil \\
\hline 1. & $\begin{array}{l}\text { Meka. M,. } \\
\text { (2017). India. }\end{array}$ & $\begin{array}{l}\text { - Tujuan penelitian: Untuk } \\
\text { mengevaluasi keunggulan } \\
\text { penggunaan balutan madu dan } \\
\text { balutan normal saline terhadap } \\
\text { peyembuhan luka kronis yang } \\
\text { tidak sembuh } \\
\text { - Desain penelitian: A } \\
\text { Prospective Randomized Study. } \\
\text { - Jumlah sampel } 42 \text { responden, } \\
\text { terdiri dari kelompok intervensi } \\
22 \text { responden dan kontrol } 20 \\
\text { responden. }\end{array}$ & $\begin{array}{l}\text { Terdapat perbedaan yang } \\
\text { signifikan secara statistik pada } \\
\text { status penyembuhan luka dengan } \\
\text { melihat ukuran luka, skor nyeri } \\
\text { dan kenyamanan balutan. } \\
\text { Pada awal penelitian, } \\
\text { Luas permukaan luka: } \\
\text { A: } 4.35(1.8-12.1) \\
\text { B:4.25 (0.8-8.6), dengan nilai p. } \\
\text { 0.0001 } \\
\text { Skor nyeri: } \\
\text { A: } 7(0-10) \\
\text { B: } 7 \text { (0-10) } \\
\text { Kenyamanan Balutan: } \\
\text { A: } 4(3-7) \\
\text { B: } 4 \text { ( 2-7) } \\
\text { Pada minggu ke 6, } \\
\text { Luas permukaan luka menurun, } \\
\text { yaitu: } \\
\text { A: 0.55 (0 -12.1) } \\
\text { B: 1.95 (0-7.8), dengan nilai } \\
\text { p.0.000 } \\
\text { Skor nyeri berkurang, yaitu: } \\
\text { A: } 1 \text { (0-4) } \\
\text { B:5 (0-9), dengan nilai p. } 0.000 \\
\text { Kenyamanan balutan meningkat: } \\
\text { A: } 9 \text { (7-10) } \\
\text { B: } 6 \text { (4-8) }\end{array}$ \\
\hline 2. & $\begin{array}{l}\text { Tsang et al., } \\
\text { (2017). } \\
\text { Hongkong. }\end{array}$ & 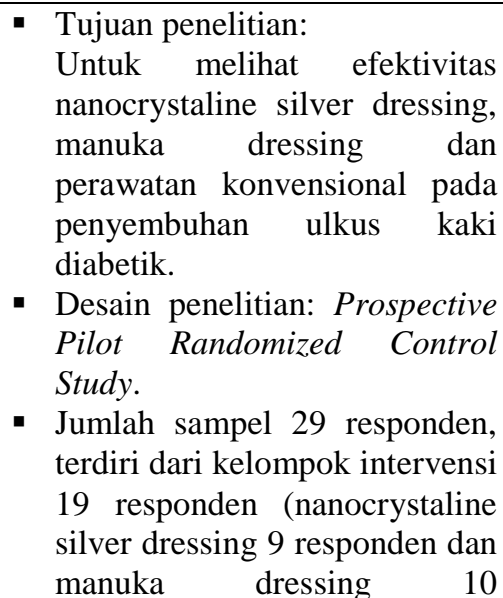 & $\begin{array}{l}\text { 1. Proporsi kesembuhan ulkus } \\
\text { total dari tiap kelompok } \\
\text { sebesar: } \\
\text { - Kelompok nanocrystaline } \\
\text { silver dressing } 81.8 \% \\
\text { - Kelompok manuka dressing } \\
\text { sebesar 50\%, } \\
\text { - Kelompok konvensional } \\
40 \% \text {. } \\
\text { 2. Tingkat pengurangan ukuran } \\
\text { ulkus berpotensi lebih tinggi } \\
\text { pada kelompok alignat } \\
\text { dressing (97.45\%), manuka } \\
\text { dressing (86.21\%), dan } \\
\text { kelompok konvensional }\end{array}$ \\
\hline
\end{tabular}




\begin{tabular}{|c|c|c|c|}
\hline & & $\begin{array}{l}\text { responden), kelompok kontrol } \\
10 \text { responden. }\end{array}$ & $(75.17 \%)$. \\
\hline 3. & $\begin{array}{l}\text { Bokaiean et } \\
\text { al. (2018). } \\
\text { Iran. }\end{array}$ & 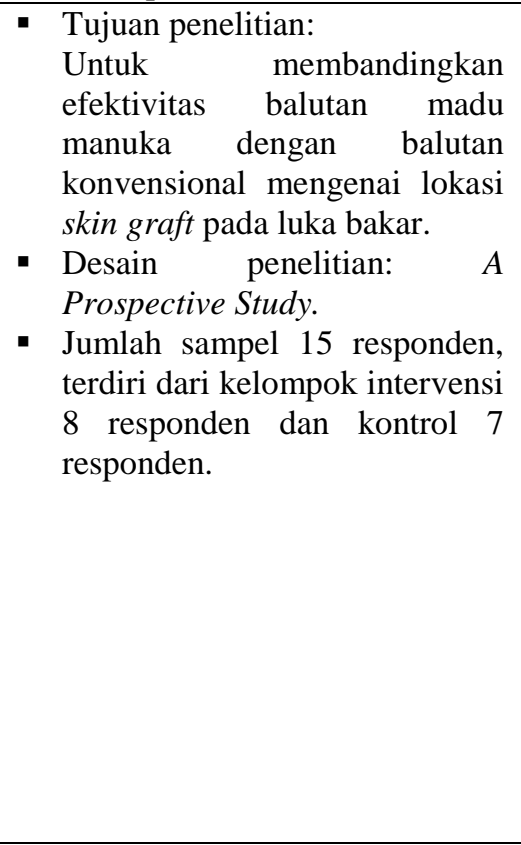 & 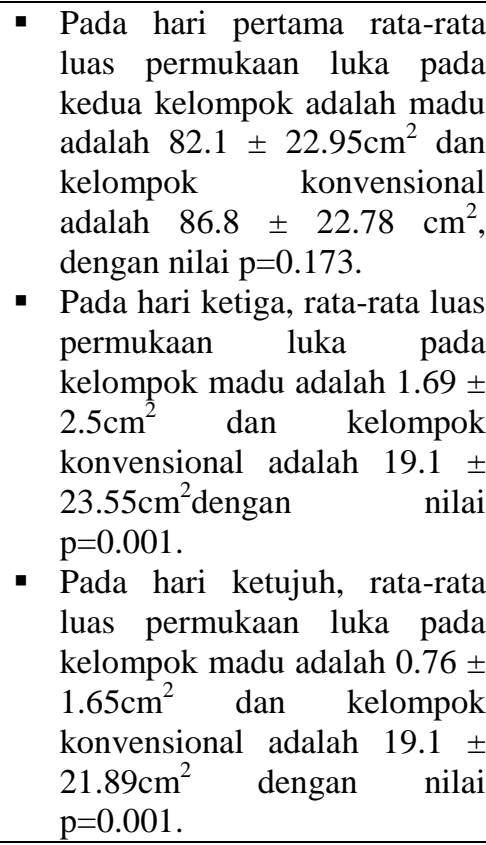 \\
\hline 4. & $\begin{array}{l}\text { Honeypalsinh } \\
\text { et al. (2019). } \\
\text { India. }\end{array}$ & $\begin{array}{l}\text { Tujuan penelitian: } \\
\text { Untuk mengevaluasi efektivitas } \\
\text { balutan madu terhadap } \\
\text { penyembuhan luka kronis dan } \\
\text { luka bakar, dengan melihat } \\
\text { waktu yang dibutuhkan untuk } \\
\text { penyembuhan luka. } \\
\text { Desain penelitian: A } \\
\text { Prospevtive Observational } \\
\text { Study. } \\
\text { Jumlah sampel } 40 \text { responden, } \\
\text { terdiri dari kelompok intervensi } \\
20 \text { responden dan kontrol } 20 \\
\text { responden. }\end{array}$ & $\begin{array}{l}\text { Penelitian ini melaporkan bahwa } \\
\text { rata-rata jumlah hari yang } \\
\text { diperlukan untuk penyembuhan } \\
\text { luka pada kelompok madu adalah } \\
12.47 \pm 4.15 \text { dan kelompok silver } \\
\text { Sulfadiazin adalah } 15.78 \pm 5.78 \text {, } \\
\text { dengan nilai } p=0.000 .\end{array}$ \\
\hline 5. & $\begin{array}{l}\text { Zeleníková \& } \\
\text { Vyhlídalová, } \\
\text { (2019). } \\
\text { Republik } \\
\text { Ceko. }\end{array}$ & $\begin{array}{l}\text { - Tujuan penelitian: } \\
\text { Untuk mengetahui efektivitas } \\
\text { madu terhadap manajemen } \\
\text { luka yang susah sembuh pada } \\
\text { pasien lansia yang dirawat } \\
\text { dirumah. } \\
\text { - Desain penelitian: } \\
\text { A Prospective Interventional } \\
\text { Study. } \\
\text { - Jumlah sampel } 40 \text { responden, } \\
\text { terdiri dari kelompok intervensi } \\
20 \text { responden dan kontrol } 20 \\
\text { responden. }\end{array}$ & $\begin{array}{l}\text { Pada awalnya, tidak ada } \\
\text { perbedaan signifikan secara } \\
\text { statistik pada ukuran luka, yaitu: } \\
\text { Ukuran luka pada hari I: } \\
\text { A: } 15.7 \mathrm{~cm}^{2} \\
\text { B: } 16.9 \mathrm{~cm}^{2} \\
\text { dengan nilai p. } 0.1801 \\
\text { Setelah } 3 \text { bulan (90 hari) terdapat } \\
\text { perbedaan signifikan secara } \\
\text { statistik dalam ukuran luka, yaitu: } \\
\text { A: } 6.0 \mathrm{~cm}^{2} \\
\text { B: } 9.8 \mathrm{~cm}^{2} \\
\text { dengan nilai p. } 0.0041 \\
\text { Intensitas nyeri pada awal tidak } \\
\text { ada perbedaan signifikan dengan } \\
\text { nilai p. } 0.1516 \\
\text { Setelah } 20 \text { hari, terdapat } \\
\text { perbedaan signifikan secara } \\
\text { statistic, yaitu: } \\
\text { A: } 1.7 \pm 1.53 \\
\text { B: } 3.8 \pm 1.70\end{array}$ \\
\hline
\end{tabular}




\begin{tabular}{|c|c|c|c|}
\hline & & & Dengan nilai p. 0.0007. \\
\hline 6. & $\begin{array}{l}\text { Koujalagi et } \\
\text { al. (2020). } \\
\text { India. }\end{array}$ & $\begin{array}{l}\text { - Tujuan penelitian: } \\
\text { Untuk mengetahui efektivitas } \\
\text { penggunan madu dan balutan } \\
\text { povidone iodine terhadap } \\
\text { pengurangan ukuran luka DFU. } \\
\text { - Desain penelitian: RCT. } \\
\text { - Jumlah sampel } 64 \text { responden, } \\
\text { terdiri dari kelompok intervensi } \\
32 \text { responden dan kontrol } 32 \\
\text { responden. }\end{array}$ & 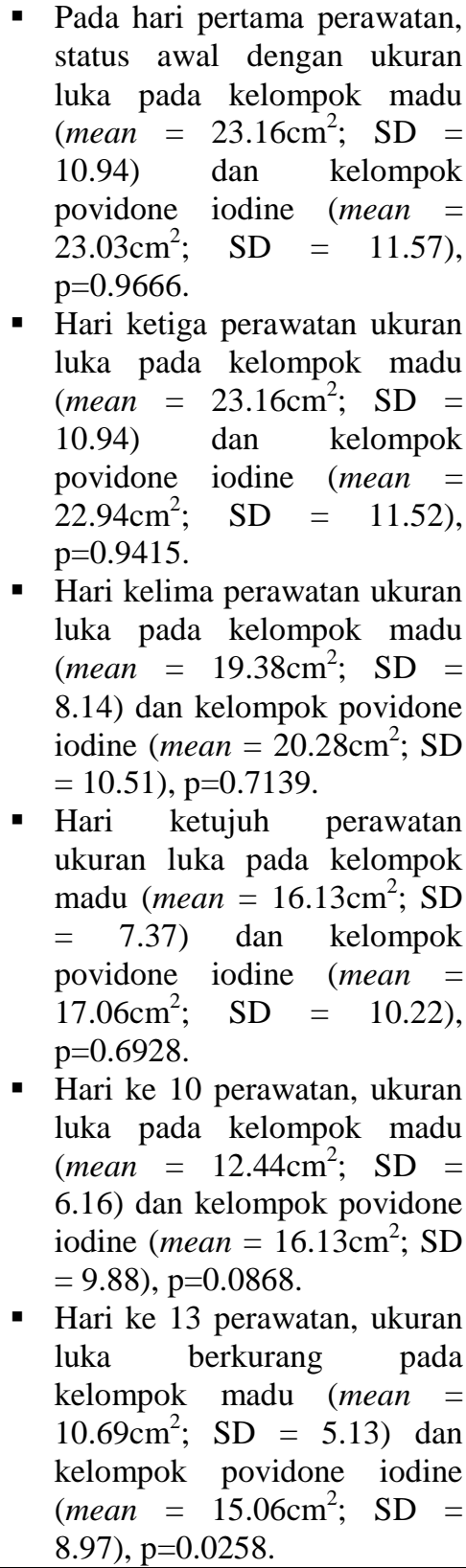 \\
\hline
\end{tabular}

Dari enam artikel penelitian yang dilakukan tinjauan literatur, lima artikel penelitian melaporkan bahwa madu efektif terhadap penyembuhan luka kronis, diantaranya melaporkan bahwa balutan madu lebih unggul dibandingkan dengan balutan normal saline dalam mencapai penyembuhan luka, mengurangi luas permukaan luka, serta meningkatkan kenyamanan balutan pada luka kronis. Madu manuka mempercepat proses penyembuhan, mengurangi nyeri, serta dapat digunakan untuk perawatan skin graft.

Balutan madu lebih efektif daripada sulfadiazin dalam penyembuhan luka bakar dan luka kronis. Penggunaan balutan madu sangat efektif dalam pengelolaan luka kronis. Balutan madu efektif untuk mengurangi ukuran luka pada diabetic foot ulcer, dan satu artikel penelitian melaporkan bahwa nanocrystalinesilver dressing lebih cepat tingkat penyembuhannya dibandingkan manuka dressing dan perawatan konvensional. 


\section{PEMBAHASAN}

Luka kronis didefinisikan sebagai luka yang gagal sembuh setelah tiga bulan. Ada berbagai faktor instrinsik dan ekstrinsik yang dapat menyebabkan berkembangnya luka kronis termasuk penyakit penyerta seperti diabetes mellitus, insufisiensi vena, faktor gaya hidup seperti obesitas, konsumsi alkohol dan merokok (Tapiwa, 2018). Madu merupakan salah satu terapi komplementer yang dapat digunakan sebagai terapi topikal dalam perawatan luka. Madu adalah cairan manis yang berasal dari nektar bunga yang dihasilkan oleh lebah yang telah digunakan secara tradisional oleh orang Mesir, Yunani, Romawi dan Cina untuk menyembuhkan luka (Pasupuleti et al., 2017).

Dari enam artikel yang dilakukan tinjauan literatur, ada lima artikel penelitian yang melaporkan bahwa penggunaan madu topikal lebih efektif dalam meningkatkan kecepatan proses penyembuhan luka kronis dibandingkan dengan povidone iodine, normal saline, sulfaidzin silver dan nanocrytaline silver (Koujalagi et al., 2020; Zeleníková \& Vyhlídalová, 2019; Bokaiean et al., 2018; Meka, 2017; Joshi et al., 2019; Tsang et al., 2017). Karena madu memiliki kandungan gula yang tinggi yang mempunyai interaksi kuat dengan molekul air sehingga dapat menghambat pertumbuhan daya hidup bakteri, sifat anti bakteri dalam mengatasi infeksi dan mengurangi bau pada luka dan sebagai anti inflamasi yang dapat mengurangi sensasi nyeri (perubahan skor nyeri), peradangan dan pembengkakan. Kandungan gula yang tinggi pada madu jika kontak dengan cairan luka, maka cairan luka akan terlarut dan luka menjadi lembab dengan kata lain bahwa lingkungan yang lembab sangat baik untuk proses penyembuhan luka (Ose et al., 2018). Adapun efek dari suasana lembab yaitu dapat mencegah dehidrasi jaringan, kematian sel, mempercepat angiogenesis, meningkatkan pemecahan jaringan mati dan fibrin serta mengurangi sensasi nyeri saat terapi atau pengobatan (Snyder et al., 2016).

Balutan madu lebih efektif dalam mencapai kesembuhan total, mengurangi luas permukaan luka, mengurangi sensasi nyeri saat penggantian balutan serta dapat meningkatkan kenyamanan balutan luka sedangkan balutan povidone iodine tidak efektif dalam mempercepat penyembuhan luka dan tidak efektif dalam mengurangi infeksi bakteriologis pada luka kronis atau luka yang susah sembuh (Zeleníková \& Vyhlídalová, 2019). Hal ini sejalan dengan penelitian Koujalagi et al., (2020) yang melaporkan bahwa madu efektif mengurangi ukuran luka pada pasien DFU. Dalam literatur dijelaskan bahwa madu memiliki potensi dalam proses penyembuhan luka antara lain bertanggung jawab terhadap aktivitas anti bakteri, anti inflamasi, anti oksidan, anti mikrobial, debridement autolitik dan stimulasi pertumbuhan sel untuk perbaikan jaringan (Nweze et al., 2020).

Madu juga meningkatkan waktu kontraksi pada luka sehingga luka cepat menutup (Minden \& Bowlin, 2018) dikarenakan kandungan nutrisi yang terdapat dalam madu. Secara umum madu mengandung 40\% glukosa, 40\% fruktosa, 20\% air dan asam amino, vitamin biotin, asam nikotinin, asam folit, asam pentonoik, proksidin, tiamin, kalsium, zat besi, magnesium, fosfor, kalium, dan juga mengandung zat antioksidan serta hidrogen peroksida sebagai penetral radikal bebas (Samarghandian et al., 2017). Hal ini didukung oleh penelitian yang menyatakan bahwa madu memberikan nutrisi yang dibutuhkan untuk regenerasi jaringan karena mengandung sejumlah besar gula yang mudah berasimilasi, mengandung banyak asam amino dan mengandung berbagai jenis vitamin terutama vitamin A diperlukan untuk pembentukan jaringan granulasi dan sintesis kolagen, epitelisasi dan fungsi makrofag (Serena et al., 2018). 
Studi penelitian lain menjelaskan bahwa madu dan komponennya mampu merangsang atau menghambat pelepasan sitokin (TNF- $\alpha$, Interleukin-1 $\beta$, dan Interleukin-6) dari monosit dan makrofag tergantung pada kondisi luka dan dapat mempercepat re-epitelisasi dan penutupan luka (Minden \& Bowlin, 2018). Namun berbeda dengan penelitian yang dilakukan oleh Tsang et al. (2017) yang hasil penelitiannya melaporkan bahwa nanocrystaline silver dressing berpotensi lebih unggul dibandingkan manuka dressing dan perawatan konvensional pada penyembuhan ulkus kaki diabetik. Hal ini dipengaruhi karena jumlah sampel kecil, hanya ada sembilan yang diobservasi selama 12 minggu sehingga tidak cukup akurat untuk menilai waktu penyembuhan yang sebenarnya.

\section{SIMPULAN}

Banyak jenis bahan dan metode yang digunakan dalam manajemen perawatan luka, namun madu sebagai salah satu modalitas perawatan luka yang efektif dalam proses penyembuhan luka, karena madu dapat mempertahankan kelembaban, merangsang pertumbuhan jaringan angiogenesis, granulasi, kontraksi luka, merangsang sintesis kolagen, memfasilitasi debridement dan mempercepat epitelisasi luka. Salah satu keunggulan madu adalah mampu melawan infeksi kuman yang resisten terhadap antibiotik. Disamping itu, madu bersifat menguntungkan artinya aman, hemat biaya, mudah didapat dan tidak berisiko.

\section{SARAN}

Hasil tinjauan literatur ini hendaknya dapat digunakan sebagai tambahan pengetahuan atau informasi bagi profesional keperawatan sehingga dapat diaplikasikan di fasilitas pelayanan kesehatan baik di rumah sakit, puskesmas maupun klinik atau home care.

\section{DAFTAR PUSTAKA}

Bokaiean, R., Momeni, M., Sabrjoo, P., Dahmardehei, M., Roham, M., \& Rahber, H. (2018). Comparing Active Leptospermum Honey Dressing with Conventional Dressing in Skin graft donor sites. Iranian Journal of Dermatology, 21(1), 1-6

Cohen-Mansfield, Maha Dakheel-Ali, MDb, Marcia S. Marx, PhDb, Khin Thein, MDb, and Natalie G. Regier, P. (2017). Biology and Biomarkers for Wound Healing. $\begin{array}{llll}\text { Physiology \& } \quad \text { Behavior, } & \text { 176(1), }\end{array}$ https://doi.org/10.1016/j.physbeh.2017.03.040

Dzugan, M., Tomczyk, M., Sowa, P., \& Grabek-Lejko, D. (2018). Antioxidant Activity as Biomarker of Honey Variety. Molecules, 23(8), 1-14. https://doi.org/10.3390/molecules23082069

Ghazali, W. S. W., Romli, A. C., \& Mohamed, M. (2017). Effects of Honey Supplementation on Inflammatory Markers among Chronic Smokers: A Randomized Controlled Trial. BMC Complementary and Alternative Medicine, 17(1), 4-9. https://doi.org/10.1186/s12906-017-1703-6

Han, G., \& Ceilley, R. (2017). Chronic Wound Healing: A Review of Current Management and Treatments. Advances in Therapy, 34(3), 599-610. https://doi.org/10.1007/s12325-017-0478-y

Henatsch, D., den Hartog, G. J. M., Duijvestijn, A. M., Wolffs, P. F., Phielix, E., Stokroos, R. J., \& Briedé, J. J. (2018). The Contribution of $\alpha$-Dicarbonyl Compound Dependent Radical Formation to the Antiseptic Effect of Honey. 
Journal of Functional Foods, 45(April), 239-246. https://doi.org/10.1016/j.jff.2018.04.012

Joret, M. O., Osman, K., Dean, A., Cao, C., van der Werf, B., \& Bhamidipaty, V. (2019). Multidisciplinary Clinics Reduce Treatment Costs and Improve Patient Outcomes in Diabetic Foot Disease. Journal of Vascular Surgery, 70(3), 806-814. https://doi.org/10.1016/j.jvs.2018.11.032

Joshi, H., Tirthkumar, R., \& Aakash, A. (2019). Effect of Honey Impregnated Dressing v/s Silver Sulfadiazine in Healing of Chronic Ulcer and Burns. International Journal of Surgery Science, 3(4), 209-216. https://doi.org/10.33545/surgery.2019.v3.i4d.242

Koujalagi, R. S., Uppin, V. M., Shah, S., \& Sharma, D. (2020). One Year Randomized Controlled Trial to Compare the Effectiveness of Honey Dressing Versus Povidone Iodine Dressing for Diabetic Foot Ulcer at Dr. Prabhakar Kore Hospital and MRC, Belagavi. International Surgery Journal, 7(2), 506. https://doi.org/10.18203/2349-2902.isj20200306

Martinotti, S., \& Ranzato, E. (2018). Honey, Wound Repair and Regenerative Medicine. Journal of Functional Biomaterials, 9(2). https://doi.org/10.3390/jfb9020034

Meka, M. (2017). Comparison of Conventional Normal Saline Dressing and Honey Dressing In the Management of Chronic Non-Healing Ulcers. Journal of Medical Science And Clinical Research, 05(03), 19214-19217. https://doi.org/10.18535/jmscr/v5i3.142

Meo, S. A., Al-Asiri, S. A., Mahesar, A. L., \& Ansari, M. J. (2017). Role of Honey in Modern Medicine. Saudi Journal of Biological Sciences, 24(5), 975-978. https://doi.org/10.1016/j.sjbs.2016.12.010

Minden, B., \& Bowlin, G. (2018). Honey-Based Templates in Wound Healing and Tissue Engineering. Bioengineering, 5(2). https://doi.org/10.3390/bioengineering5020046

Nweze, A. J., Olovo, V. C., Innocent, N. E., Okechukwu, J. O., \& Paul, C. (2020). Therapeutic Properties of Honey. Honey Analysis - New Advances and Challenges, 1-21. https://doi.org/10.5772/intechopen.86416

Ose, M., Utami, P., \& Damayanti, A. (2018). Efektivitas Perawatan Luka Teknik Balutan Wet-Dry dan Moist Wound Healing pada Penyembuhan Ulkus Diabetik. Journal of Borneo Holistic Health, 1(1), 101-112

Pasupuleti, V. R., Sammugam, L., Ramesh, N., \& Gan, S. H. (2017). Honey, Propolis, and Royal Jelly: A Comprehensive Review of Their Biological Actions and Health Benefits. Oxidative Medicine and Cellular Longevity, 2017. https://doi.org/10.1155/2017/1259510

Samarghandian, S., Farkhondeh, T., \& Samini, F. (2017). Honey and Health: A Review of Recent Clinical Research. Pharmacognosy Research, 9(2), 121-127. https://doi.org/10.4103/0974-8490.204647

Serena, T. E., Yaakov, R. A., DeLegge, M., Mayhugh, T. A., \& Moore, S. (2018). Nutrition in Patients with Chronic Non-Healing Ulcers: A Paradigm Shift in Wound Care. Chronic Wound Care Management and Research, Volume 5, 5-9. https://doi.org/10.2147/cwcmr.s155114 
Snyder, R. J., Fife, C., \& Moore, Z. (2016). Components and Quality Measures of DIME (Devitalized Tissue, Infection/Inflammation, Moisture Balance, and Edge Preparation) in Wound Care. Advances in Skin and Wound Care, 29(5), 205-215. https://doi.org/10.1097/01.ASW.0000482354.01988.b4

Syam, Y., Natsir, R., Rahardjo, S. P., Usman, A. N., Dwiyanti, R., \& Hatta, M. (2016). Effect of Trigona Honey to mRNA Expression of Interleukin-6 on Salmonella Typhi Induced of BALB/c Mice. American Journal of Microbiological Research, 4(3), 77-80. https://doi.org/10.12691/ajmr-4-3-2

Tapiwa, C. E. (2018). Clinical Management of Non-Healing Wounds. Nursing Standard, 32(29), 48-63. https://doi.org/10.7748/ns.2018.e10829

Tsang, K. K., Kwong, E. W. Y., To, T. S. S., Chung, J. W. Y., \& Wong, T. K. S. (2017). A Pilot Randomized, Controlled Study of Nanocrystalline Silver, Manuka Honey, and Conventional Dressing in Healing Diabetic Foot Ulcer. Evidence-Based Complementary and Alternative 2017. https://doi.org/10.1155/2017/5294890

Wang, H., Horng, H., Ching, C., \& Chen, Y. J. (2017). Wound Healing. Journal of the Chinese Medical Association, 81(2), 94-101. https://doi.org/10.1016/j.jcma.2017.11.002

Weller, C., Weller, C., \& Team, V. (2019). Interactive Dressings and Their Role in Moist Wound Management. In Advanced Textiles for Wound Care (Second Edi). Elsevier Ltd. https://doi.org/10.1016/b978-0-08-102192-7.00004-7

Zeleníková, R., \& Vyhlídalová, D. (2019). Applying Honey Dressings to Non-Healing Wounds in Elderly Persons Receiving Home Care. Journal of Tissue Viability, 28(3), 139-143. https://doi.org/10.1016/j.jtv.2019.04.002

Zhang, X., Shu, W., Yu, Q., Qu, W., Wang, Y., \& Li, R. (2020). Functional Biomaterials for Treatment of Chronic Wound. Frontiers in Bioengineering and Biotechnology, 8(June), 1-15. https://doi.org/10.3389/fbioe.2020.00516 